\section{BROAD-SPECTRUM DERIVATIVES OF POLYMYXIN B AND COLISTIN}

Sir :

The polymyxins and circulins comprise a group of strongly basic decapeptide antibiotics composed of a cyclic heptapeptide moiety with a tripeptide side-chain containing the acyl residue of S-(+)6-methyl octanoic acid or 6-methyl heptanoic acid. The structure of the two clinically important polymyxins, polymyxin B and colistin (polymyxin E), has been elucidated by total synthesis by Vogler et al. ${ }^{1)}$ and StUder et al. ${ }^{2)}$ respectively.

The polymyxins show high activity against most gram-negative bacteria (with the exception of the Neisseria and Proteus spp.) while most gram-positive bacteria are resistant. Following the repor $t^{8)}$ of the colistin derivative penta $\mathrm{N}^{r}$ butyl colistin having significantly higher activity against Staphylococcus aureus than colistin itself, we decided to prepare and test out some substituted penta $\mathrm{N}^{r}$-benzylidene polymyxin $\mathrm{B}$ and colistin derivatives as well as the corresponding penta $\mathrm{N}^{\top}$-benzyl polymyxin $\mathrm{B}$ and colistin derivatives.

The derivatives prepared can be represented by the following formulae, where PB stands for penta $\mathrm{N}^{r}$-desamino polymyxin $\mathrm{B}$ and $\mathrm{Col}$ stands for penta $\mathbf{N}^{\gamma}$-desamino colistin:

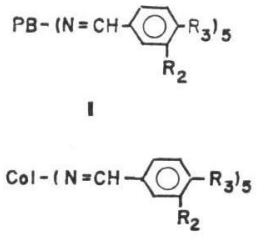

III

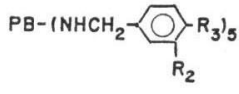

11

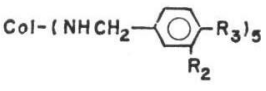

IV
The SCHIFF bases (I and III) were prepared by reacting polymyxin $\mathbf{B}$ or colistin with an excess of the corresponding substituted benzaldehyde in an organic solvent. The reduction of the SCHIFF bases to the derivatives II or IV was performed with sodium borohydride as the reducing agent. Neither the catalytic reduction $^{3)}$ nor the LEUCKART-WALLACH reaction ${ }^{4}$ ) worked well in our hands.

The following general methods were used for the preparation of these derivatives:

To prepare the SCHIFF bases I or III, 5 mmoles of polymyxin $\mathrm{B}$ base $(6.0 \mathrm{~g})$ or colistin base
$(5.8 \mathrm{~g})$ was stirred at room temperature with 32 mmoles of the appropriate benzaldehyde in a mixture of $50 \mathrm{ml}$ methanol and $50 \mathrm{ml} \mathrm{N}, \mathrm{N}$ dimethylformamide until all had dissolved (usually 2 days). The solution of the Schiff bases was filtered through Celite and added under rapid stirring to 10 volumes of dry ether. The mixture was stirred for 30 minutes, the precipitate was filtered and washed with dry ether. The precipitate was dried and redissolved in a mixture of dioxan and ethanol and reprecipitated with ether and dried in vacuum over sulfuric acid.

This method gave the derivatives I and III as amorphous powders, usually in high yields. The identity was checked by ${ }^{1} \mathrm{H}-\mathrm{NMR}\left(\mathrm{d}_{6}-\mathrm{DMSO}\right.$ $\mathrm{D}_{2} \mathrm{O}(3: 1)$ ), the spectra showed the theoretical ratio of upfield aliphatic protons $(\delta 0.8 \sim 2.2 \mathrm{ppm}$ relative to tetramethylsilane) to aromatic and aldimine protons $(\delta 6.8 \sim 8.3 \mathrm{ppm})$. The purity of the products was higher than $99 \%$ by perchloric acid titration in glacial acetic acid.

To prepare the derivatives II and IV, isolation of the SCHIFF base intermediates was not necessary. Thus, the above filtered solution of the SCHIF base from 5 mmoles of polymyxin B or colistin was added to an ice-cooled, stirred suspension of $4 \mathrm{~g}$ (100 mmoles) sodium borohydride in $150 \mathrm{ml}$ 2-propanol taking care that the temperature did not exceed $7^{\circ} \mathrm{C}$. The mixture was stirred on an ice-bath until all the sodium borohydride had dissolved and then for a further 3 hours at room temperature. The solution was poured to a vigorously stirred mixture of $500 \mathrm{~g}$ crushed ice and $1,000 \mathrm{ml}$ water containing $2 \mathrm{~g}$ sodium carbonate. The $\mathrm{pH}$ was adjusted to 9.5 9.8 with dilute sulfuric acid. The precipitate was separated by filtration, dried and redissolved in a dioxan - ethanol mixture. The solution was clarified through Celite and poured into 10 volumes of vigorously stirred dry ether. The product was filtered, washed with dry ether and dried in vacuum over concentrated sulfuric acid.

The derivatives so obtained were amorphous or microcrystalline powders, the ${ }^{1} \mathrm{H}-\mathrm{NMR}$ showing the expected ratio of aromatic $(\delta 6.8 \sim$ $8.0 \mathrm{ppm})$ to upfield aliphatic protons $(\delta 0.8 \sim$ $2.2 \mathrm{ppm}$ ) and with no evidence of aldimine protons ( $\delta 8.3 \mathrm{ppm}$ approx.). The derivatives were homogenous on high-voltage paper electrophoresis $(70 \mathrm{~V} / \mathrm{cm}$, formic acid (1:100), ninhydrin detection) and had a purity of $94 \sim 99 \%$ 
as judged by titration with perchloric acid in glacial acetic acid.

The minimum inhibitory concentration (MIC) of the derivatives was determined against Staphylococcus aureus ATCC 6538P and Escherichia coli strain 14. The MICs of II and IV were determined by preparing two-fold dilution series in 1.2-propandiol and adding $0.1 \mathrm{~m}$ to test-tubes containing $10 \mathrm{ml}$ seeded Penassay broth at $\mathrm{pH} 8$ $S$. aureus, approx. $5 \times 10^{5}$ cells $/ \mathrm{ml}$; E. coli: approx. $10^{6}$ cells $/ \mathrm{ml}$ ). The MICs of I and III were determined similarly at $\mathrm{pH} 8$. After incubation at $37^{\circ} \mathrm{C}$ for 24 hours, the tubes were inspected for growth.

The derivatives prepared and tested for antibacterial activity are shown in Table 1 together with the yields of preparation.

As can be seen from Table 1 some of the penta N-benzyl derivatives show a marked increase in activity against $S$. aureus as well as a

Table 1. The antibacterial activity of some substituted penta $\mathrm{N}^{\delta}$-benzylidene and penta $\mathrm{N}^{\delta}$-benzylpolymyxin $\mathrm{Bs}$ and penta $\mathrm{N}^{\delta}$-benzylidene and penta $\mathrm{N}^{\delta}$-benzyl colistins

\begin{tabular}{|c|c|c|c|c|c|}
\hline \multirow{2}{*}{$\begin{array}{l}\text { Com- } \\
\text { pound }\end{array}$} & \multirow{2}{*}{$\mathrm{R}_{2}$} & \multirow{2}{*}{$\mathrm{R}_{3}$} & \multirow{2}{*}{$\underset{\%}{\text { Yield }}$} & \multicolumn{2}{|c|}{$\mathrm{MIC} \mu \mathrm{g} / \mathrm{ml}$} \\
\hline & & & & S.aureus & E. coli \\
\hline Pol. B & - & - & - & 120 & 0.31 \\
\hline Ia & $\mathrm{H}$ & $\mathrm{H}$ & 86 & 12 & 0.0 \\
\hline Ib & $\mathrm{H}$ & $\mathrm{OH}$ & 85 & 26 & - \\
\hline Ic & $\mathrm{OCH}_{3}$ & $\mathrm{OH}$ & 59 & 26 & - \\
\hline Id & $\mathrm{H}$ & $\mathrm{N}\left(\mathrm{CH}_{3}\right)_{2}$ & 78 & 26 & - \\
\hline IIa & $\mathrm{H}$ & $\mathrm{H}$ & 61 & 1.3 & 5 \\
\hline IIb & $\mathrm{H}$ & $\mathrm{OH}$ & 81 & 1.6 & 6.2 \\
\hline IIc & $\mathrm{OCH}_{3}$ & $\mathrm{OH}$ & 91 & 12 & 724 \\
\hline IId & $\mathrm{H}$ & $\mathrm{N}\left(\mathrm{CH}_{3}\right)_{2}$ & 47 & 3.1 & 12 \\
\hline IIe & $\mathrm{H}$ & $\mathrm{CH}\left(\mathrm{CH}_{3}\right)_{2}$ & 96 & 6.2 & 12 \\
\hline Col. & - & - & - & $>350$ & 0.08 \\
\hline IIIa & $\mathrm{H}$ & $\mathrm{H}$ & 60 & 26 & 0.08 \\
\hline IIIc & $\mathrm{OCH}_{3}$ & $\mathrm{OH}$ & 78 & 26 & - \\
\hline IIId & $\mathrm{H}$ & $\mathrm{N}\left(\mathrm{CH}_{3}\right)_{2}$ & 97 & 26 & - \\
\hline IVa & $\mathrm{H}$ & $\mathrm{H}$ & 56 & 1.3 & 5 \\
\hline IVb & $\mathrm{H}$ & $\mathrm{OH}$ & 62 & 1.4 & 5.5 \\
\hline IVe & $\mathrm{OCH}_{3}$ & $\mathrm{OH}$ & 81 & 2.8 & 5.5 \\
\hline IVd & $\mathrm{H}$ & $\mathrm{N}\left(\mathrm{CH}_{3}\right)_{2}$ & 70 & 3.1 & 12 \\
\hline
\end{tabular}

decrease in activity against the highly sensitive E. coli strain 14. Interestingly, one or more of the species present in aqueous solutions of the SCHIFF bases (I and III) show greater activity against $S$. aureus at $\mathrm{pH} 8$ than the parent antibiotic. It seems to be a general trend that increasing the lipophilic character of polymyxins by introducing substituted benzyl groups leads to derivatives with increased activity against $S$. aureus and a reduced activity against $E$. coli.

A preliminary investigation of the mode of action of penta $\mathrm{N}^{\gamma}$-benzyl colistin (IVa) against $S$. aureus ATCC 6538P has shown that addition of IVa to a suspension of washed cells of $S$. aureus in $1 \%$ sodium chloride ( $\mathrm{pH} 7$ ) leads to a rapid irreversible binding of the compound to centrifugable cell structures, rapid cell-death followed by a release of cytoplasmatic constituents ( $260 \mathrm{~nm}$ absorbing material).

\section{N. M. WITZKE \\ H. HedING*}

Department of Applied Biochemistry The Technical University of Denmark, DK-2800

Lyngby/Copenhagen, Denmark

(Received October 4, 1976)

\section{References}

1) Vogler, K.; R. O. Studer, P. Lanz, W. Lergier \& E. BöHnI: Synthesen in der Polymyxin-Reihe. 9 Mitt. Synthese von Polymyxin $B_{1}$. Helv. Chim. Acta 48: 1161 1177, 1965

2) Studer, R. O.; W. Lergier, P. Lanz, E. BÖHNI \& K. VOGLeR: Synthesen in der Polymyxin-Reihe. 10 Mitt. Die Synthese von Colistin A (Polymyxin $\mathrm{E}_{1}$ ). Helv. Chim. Acta 48: $1371 \sim 1378,1965$

3) Japanese Patent Application No. 62906, 1967 (to Kayaku Koseibusshitsu Kenkyusho K.K.)

4) Japanese Patent No. 101460, 1970 (to Kayaku Antibiotics Res. Co., Ltd.)

\footnotetext{
* To whom all mail should be addressed.
} 